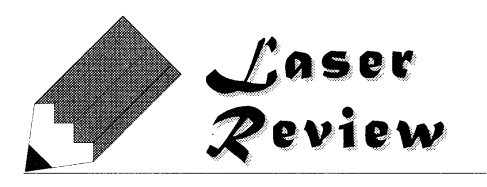

\title{
高速光ファイバ通信における偏波モード分散の補償
}

\author{
戸田 裕之，松本 正行，ダニエレアルゼッタ \\ 大阪大学大学院工学研究科通信工学専攻 (テ 565-0871 大阪府吹田市山田丘2-1)
}

\section{Compensation of Polarization Mode Dispersion for High-Speed Optical Fiber Transmission Systems}

\author{
Hiroyuki TODA, Masayuki MATSUMOTO and Daniele ALZETTA \\ Department of Communications Engineering, Graduate School of Engineering, Osaka University, \\ 2-1 Yamada-Oka, Suita, Osaka 565-0871
}

(Received August 27, 2004)

\begin{abstract}
In optical fiber transmission systems, polarization mode dispersion (PMD), represents a severe source of degradation as the bit rate increases. In this paper, we review PMD compensation techniques performed in optical domain. We also report our experimental results on PMD compensation by distributing linear polarizers along the transmission line. Polarizers are used as PMD compensator elements with only 1 degree-of-freedom (DOF) which result in simple configuration and fast response. Even though the polarizers do not compensate 1st-order PMD perfectly, Distributed 4 polarizers outperformed a 2-DOF polarizer-based PMD compensator placed at the optical receiver front-end.
\end{abstract}

Key Words: Optical fiber communication, Polarization mode dispersion (PMD), PMD compensation, Polarizers, Polarization control

1.はじめに

基幹系光ファイバ伝送システムは，様々な要素技術の 発展によって，大容量化，長距離化が実現されてきた。 このうち光ファイバ伝送路では，これまでは，損失の低 減，および群速度分散と非線形光学効果をうまく制御す ることが重要であったといえる。これらとは別に，シス テムの高速化に伴い，これまで問題にはならなかった偏 波モード分散(PMD: polarization mode dispersion)が伝送特 性に深刻な影響を与える場合が出てくるようになった。 PMDは時間的に変化する現象であるため，その補償には 多くの場合，フィードバック制御が行われる．システム によっては $100 \mu \mathrm{s}$ オーダ以下の応答速度でPMD補償を行う 必要があり, 制御パラメー夕の多い夕イプの補償器では 所望の応答を得ることは難しい。これに対して最近，制 御パラメータの少ない簡易型PMD補償器を伝送路途中に 複数分布的に配置して，補償特性を改善する方法が提案 された。補償のための制御回路が簡易化でき，高速の PMD補償が実現できる可能性がある。本稿では，PMDに ついて概略を説明し，その光領域での各種補償方法につ いて述べる。ささらに，最近筆者らが行った，偏光子を用 いた分布型PMD補償実験について述べる。
2. 偏波モード分散

通常の単一モードファイバでは，横方向からの応力や ねじれが加わったり, 横断面構造が真円からずれている と複屈折が生じる1). Fig. 1のように, 時間領域でみれば, 発生した複屈折によって二つの直交偏光間に群遅延時間 差 (DGD: differential group delay) が生じ，光信号波形の歪 みの原因となる．周波数領域でみれば，出射光の偏光状 態 (SOP: state of polarization)が光周波数によって変化する ことになる。

PMDを, ファイバ伝送後の出射光のSOPをポアンカレ 球面上で表して説明する2,3). 以下の議論では，偏波依存 損失はないものとする。偏波保存ファイバのように直交 導波モード間の結合がない場合は，出射光のSOPは光周波 数Wの変化に伴い, 複屈折の主軸に対応した点を結んだ軸 を中心として回転する。したがって，SOPの軌跡はポアン カレ球面上の小円となる。ここで, 出射光のSOPを示すス トークスベクトルを $\boldsymbol{S}$ とて, PMDベクトル $\boldsymbol{\Omega}$,

$\frac{d s}{d \omega}=\boldsymbol{W} \times \boldsymbol{S}$

と定義する， $\Omega$ は，SOP軌跡の回転軸方向 $\boldsymbol{q}$ を向き，その 大きさはDGD $\Delta \tau$ に比例する。

$\mathbf{\Omega}=\Delta \tau \boldsymbol{q}$ 


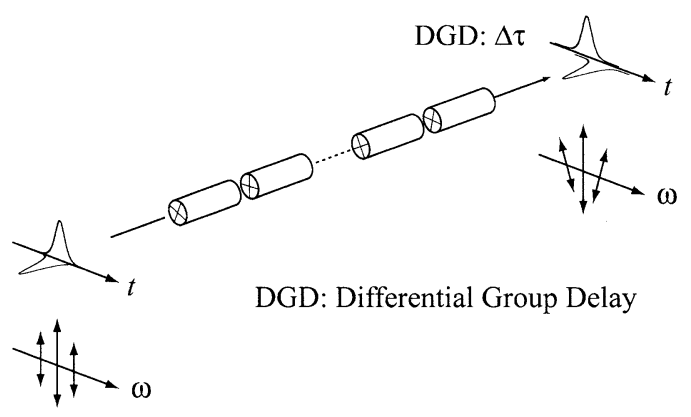

Fig. 1 Origin of the polarization mode dispersion (PMD).

通常の単一モードファイバの場合, 複屈折の大きさや 主軸の方向はファイバ長手方向に変化するためにモード 間の結合が生じ，出射光のSOPは $\omega$ の変化に対して複雑に 変化する (Fig. 2). しかしながら, 図に示したように光周 波数変化の小さい範囲では, SOPの軌跡はポアンカレ球面 上の小円と近似してょい.この時, 式(1)で近似できる PMDを1次PMDという。また, SOPの回転軸とポアンカレ 球表面との交点 $\mathrm{P}_{1}, \mathrm{P}_{2}$ に対応する2つの偏光状態を主偏光 状態または固有偏光状態 (PSP: principal state of polarization) という.ファイバ入射端からPSPの光を入射すると, 1次 $\mathrm{PMD}$ にる波形歪みは起こらない. 光周波数変化が大き くなると, すなわち光信号带域が広くなると, $\boldsymbol{\Omega}(\omega)$ の周 波数に対する変化の影響を考慮しなければならない.

$$
\frac{\partial \boldsymbol{\Omega}(\omega)}{\partial \omega}=\frac{\partial \Delta \tau}{\partial \omega} \boldsymbol{q}+\Delta \tau \frac{\partial \boldsymbol{q}}{\partial \omega}
$$

式(3)は2次PMDを表したもので, 右辺第一項は, PSP間 で符号の異なる群速度分散に対応する. 第二項は偏光度 の劣化 (depolarization) に対応する4). 偏波多重を用いない 場合，第一項による波形歪みが問題となる。一般に光周 波数の带域が1/DGDを超える領域では，2次以上のPMDの 影響も考慮する必要がある5).

単一モードファイバの複屈折は, 周囲温度や振動など まわりの環境によっても変化するから, PMDベクトルは 時間的に変動する.PMDベクトルの各成分の変化がラン

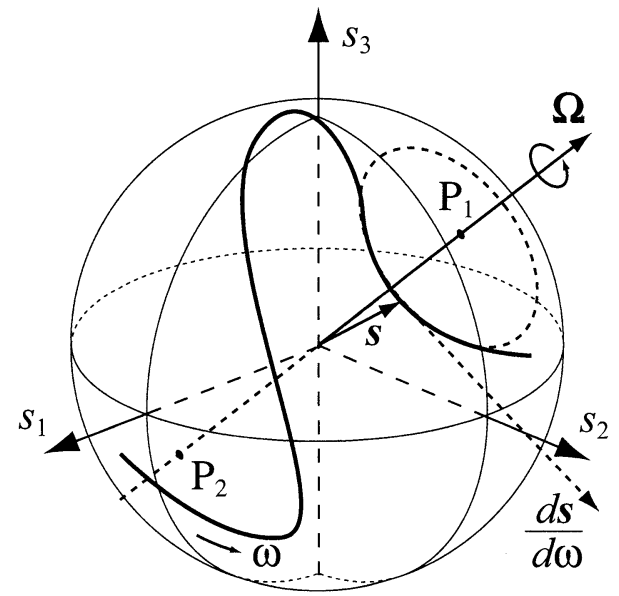

Fig. 2 A trace of the state of polarization of the output light transmitted through a standard single-mode fiber with respect to optical frequency $\omega$.
ダムであるとすると, DGDはマクスウェル分布に従う. 地中や海底に敷設された光ファイバケーブルなら, 変動 は数十分〜時間オーダのゆっくりしたものである6,7)が, 例えば線路沿いに敷設された光ファイバでは，列車から の振動によってmsオーダの変動が観測される。このよう な環境では, $100 \mu \mathrm{s}$ オーダ以下の応答速度でPMD補償を行 う必要がある。また，ファイバ長手方向にも複屈折はラ ンダムに変化するから，ファイバ伝送路全体のDGDは， ファイバ長の平方根に比例する ${ }^{8)}$. 単一モードファイバの $\mathrm{PMD}$ の大きさの評価にはPMD係数 $D_{p}[\mathrm{ps} / \sqrt{\mathrm{km}}]$ が用いられ る.

いま，ビット間隔の $10 \%$ \%で平均DGDが許容されると すると, ファイバのPMD係数が $0.1 \mathrm{ps} / \sqrt{\mathrm{km}}$ の場合, 10 Gbit/sでは伝送距離は10,000 kmであるが，40 Gbit/sでは600

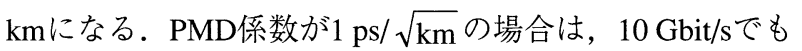
伝送距離は $100 \mathrm{~km}$ に，40 Gbit/sでは6 kmに制限される。最 近ではPMD係数が $0.1 \mathrm{ps} / \sqrt{\mathrm{km}}$ を下回るファイバは比較的 容易に作成できる。しかしながら，NoutsiosとPoirierの報 告によると，北米で敷設されたファイバの約 $20 \%$ \% 1 $\mathrm{ps} / \sqrt{\mathrm{km}}$ 以上のPMD係数を示している9). したがって，40 Gbit/sベースの長距離基幹系伝送路を構築する場合や, 既 設ファイバを利用して伝送速度をアップデートする場合 に，PMDは留意すべき問題となる。

\section{3. 各種偏波モード分散補償}

これまでに検討されてきた主な光領域でのPMD補償器 の構成をFig. 3にまとめた10,11)。前節で述べたように， PMDは時間的に変化する現象であるから, 適応的な補償 が必要になる。多くの場合, 受信器側から制御信号を フィードバックして補償器を制御する。本稿では，制御 パラメータの数を自由度と呼ぶ. Fig. 3(a)は, 送信器端で ファイバへの入射光のSOPを偏光制御素子によって伝送路 のPSPに調整する12)もので, 1次PMDが補償できる。送信 信号のSOPが直線偏光なら, 偏光制御素子は2枚の波長板 で構成できるので自由度は2である。しかしながら, 受信 器から制御信号を送信器まで伝送させなければならない から, 高速の制御は困難である. Fig. 3(b) から (e)は, 受 信器側で補償を行うものである. Fig. 3(b)は, 偏光制御素 子と可変遅延線を組み合わせた構成である ${ }^{13)}$. 偏光制御 素子で伝送後のPSPを直交直線偏光に変換し, 可变遅延線 でDGDを補償する。自由度は3で，1次PMDが補償でき る. Fig. 3(c)のように, 遅延時間を固定としたものも提案 されている14). 補償可能なDGDの範囲が制限されるが, 自由度が2となる. Fig. 3(d) は, 偏光制御素子と遅延線の 組を複数接続した構成である ${ }^{15-17)}$. 多段接続とすること で, 高次PMDも補償できる。すなわち, 波長带域の広い WDMシステムにおいても，1つの補償器で全チャネルを 一括して補償することが可能となる。しかしながら，自 由度が多くなると制御が難しくなるので, チャネルあた りの伝送速度の小さなWDMシステムでは, 数チャネルご とに1次PMD補償器を設ける方法も有力と考えられる. Fig. 3(e) は, 伝送光のPSPを固定偏光子の主軸に一致した 
(a)

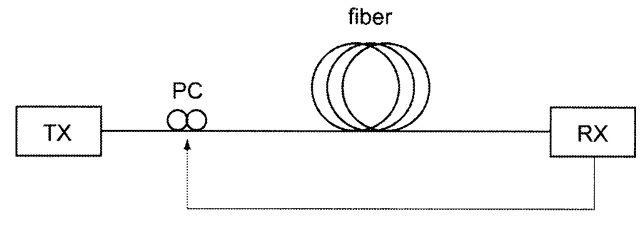

(b)

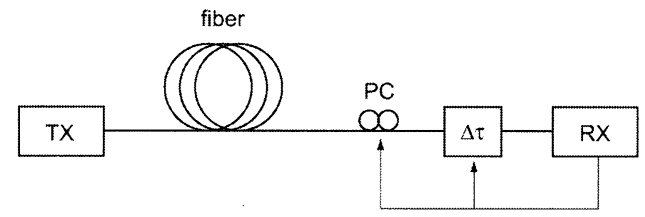

(c)

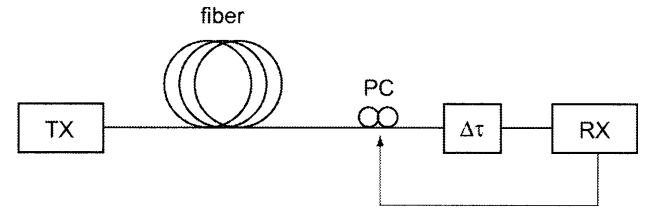

(d)

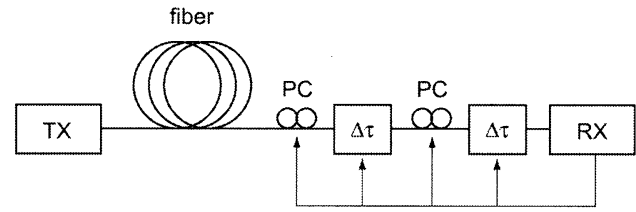

(e)

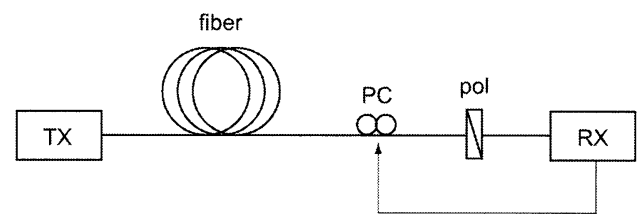

Fig. 3 PMD compensator schemes.

直線偏光に変換するものである ${ }^{18,19)}$. 偏光子の損失 (補償 時で最大 $3 \mathrm{~dB}$ ) があるものの, 自由度 $2 て ゙ 1$ 次PMDが補償で きる.フィードバック制御は, 偏光子透過光パワーが最 大となるように行う方法 ${ }^{18)}$ と, 受信信号のRFキャリア成 分が最大となるように行う方法 ${ }^{19)}$ が提案されている。前 者の方法では, 補償特性がやや劣るものの, 制御信号の 生成が非常に簡単に行えるという特長がある。

最近, 1次PMD補償器をファイバ伝送路に複数分布的に 配置する方法が提案された20,21)。分布的に配置すること で，高次PMDの影響をある程度抑圧することができる１ 1 次PMD補償器としてFig. 3(e)に示した偏光子による補償器 を用いれば, 補償器出力のSOPは常に一定であるから, 各 補償器を独立に制御することができる。このことは，補 償器の配置数を多くしても，制御の速度が低下しないこ とを示す.さらに，ファラデー回転子と固定偏光子で構 成された簡易型補償器を分布的に配置する方法が提案さ れている22)。各補償器は自由度1であるが，1次PMDを部 分的にしか補償できない。例えば，PSPが直交円偏光の場 合は，DGDによる波形歪みは補償器を通っても低減しな い. しかしながら, 分布配置数を多くすることで, 受信 器に配置された1次PMD補償器よりも優れた補償特性が得 られることが数值計算によって示されている. 文献22で は, 光中継増幅器前段に補償器を配置し, 光増幅器の利
得飽和を利用して補償器出力光パワーの変動を抑制して いる. 一方, 各補償器を光中継増幅器直後に配置し, 光 増幅器の出力光パワー制御ループ内に組み込んで, 補償 器は光パワー制御より十分速い応答速度で制御する方法 も, ASE雑音電力低減の観点から有力と考えている.

\section{4. 偏光子による分布型偏波モード分散補償実験}

偏光子による分布型PMD補償の効果を確認するための 実験を行った ${ }^{23)}$. Fig. 4に実験系を示す．実験では，10 Gbit/sのRZ光パルスをPMDエミュレータに通し, 分布型 PMD補償器の配置数によってパワーペナルティがどのよ うに変化するかを測定する．波長1550 nmのDFBレーザー の連続出力光をニオブ酸リチウム強度変調器 (LN変調器; LNM1)で切り出して繰り返し周波数 $10 \mathrm{GHz}$ のチャープフ リーRZ光パルスを生成した。 パルス幅は33 psである。次 段のLN変調器 (LNM2)を10 Gbit/sのNRZ疑似ランダム信号 (PN31段)で駆動して10 Gbit/sの光パルスとした.PMD工 ミュレータは，長さ $12 \mathrm{~m}$ の偏波保存ファイバ(PMF)2本を 2枚の1/4波長板を介して接続したものである．波長板の角 度を変化させることで，DGDを変化させることができ る。PMFのDGDは $1.5 \mathrm{ps} / \mathrm{m}$ である。この值から，4個の PMDエミュレータを直列接続した時の平均DGDは，マク スウェル分布を仮定すると $47 \mathrm{ps}$ と見積もることができ る24). PMD補償器には手動回転偏光子を用い, 偏光子後 の透過光パワーが最大となるように偏光子の角度を調節 した。

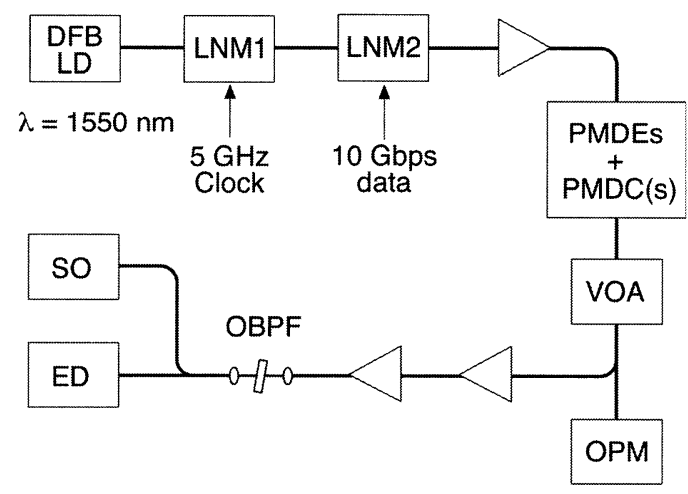

$\mathrm{LNM}: \mathrm{LiNbO}_{3}$ intensity modulator, PMDE: PMD emulator, PMDC: PMD compensator, VOA: variable optical attenuator OPM: optical power monitor, OBPF : optical bandpass filter SO: sampling oscilloscope, ED: error detector

(a)

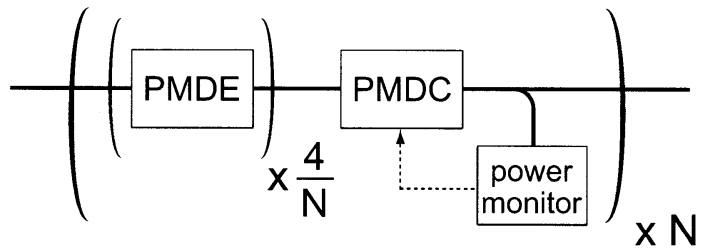

(b)

Fig. 4 Experimental setup for distributed PMD compensation using linear polarizers. (a) Whole setup. (b) Distribution arrangement of PMD emulators and compensators, where $\mathrm{N}$ is the number of PMD compensators. 
まず，PMDエミュレータと補償器を接続しないback-tobackの状態で符号誤り率 (BER) を測定し, 可変光アッテ ネータVOAを調節してBER $=10^{-9}$ となる光パワー (受信感 度) $\mathrm{P}_{0}[\mathrm{dBm}]$ を測定した。次にエミュレータと補償器を接 続した時の受信感度 $\mathrm{P}_{1}[\mathrm{dBm}]$ を測定し，パワーペナルティ $\left(=\mathrm{P}_{1}-\mathrm{P}_{0}\right)$ を求めた。測定は，PMDエミュレータの1/4波 長板の角度を変えながら256通り行い，パワーペナルティ が $1 \mathrm{~dB}$ たは $2 \mathrm{~dB}$ 以上となる確率(本稿では不稼働率と呼 ぶ）を求めた。1 0 -5以下といった不稼働率25)を求めるに は，自動制御を行って測定点を大幅に増やす必要があ る.

本実験では，偏光子による最大 $3 \mathrm{~dB}$ の損失の影響は測定 にはかからない，補償器による波形歪み改善の効果たけ を測定することになる。Fig. 5は観測したアイパターンの 代表例である。分布段数を増やしていくほど歪みの少な い良好なアイが得られている。

Fig. 6は配置数 $N=1 ， 2 ， 40$ 時に得られたパワーペナル ティのヒストグラムである。N=1と2では， $3 \mathrm{~dB}$ を超える パワーペナルティが見られるが，N=4とするとパワーペ ナルティは大きく改善されていることがわかる。Table 1 に 平均パワーペナルティと，不稼働率をまとめた。比較の

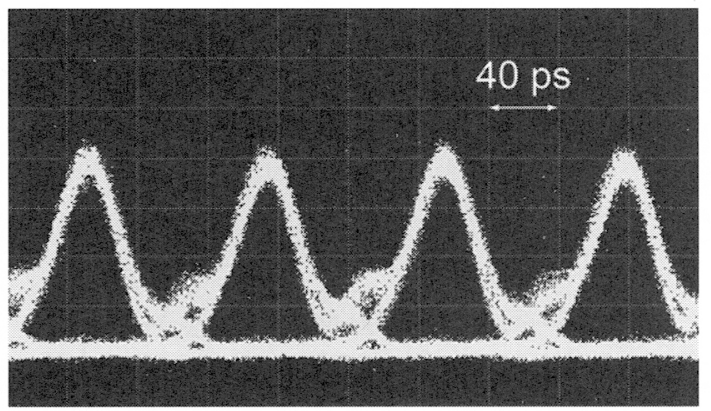

(a)

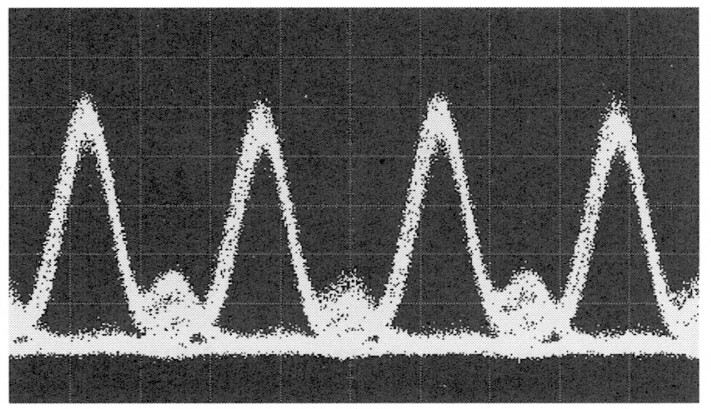

(b)

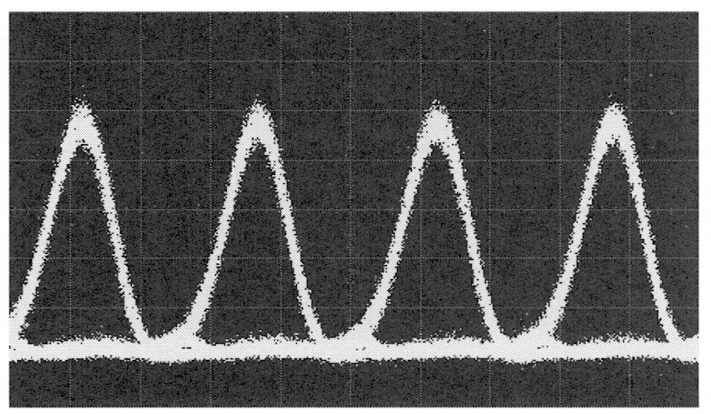

(c)

Fig. 5 Examples of observed waveforms ( $40 \mathrm{ps} / \mathrm{div}$ ) when (a) $\mathrm{N}=1$, (b) $\mathrm{N}=2$, and (c) $\mathrm{N}=4$, respectively.

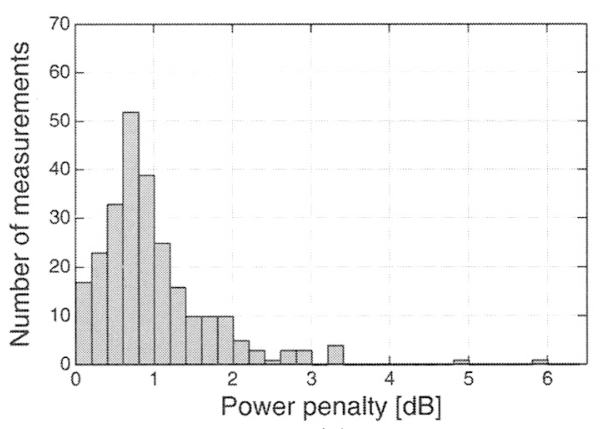

(a)

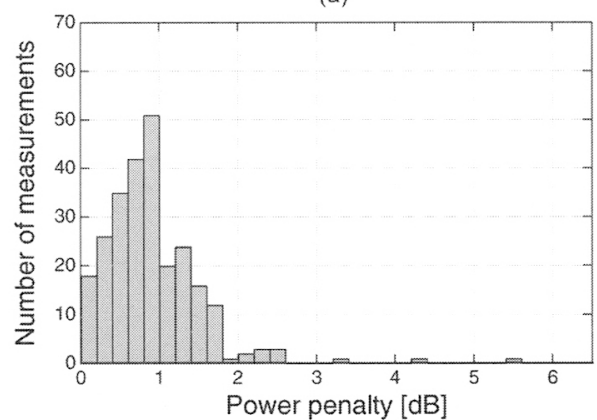

(b)

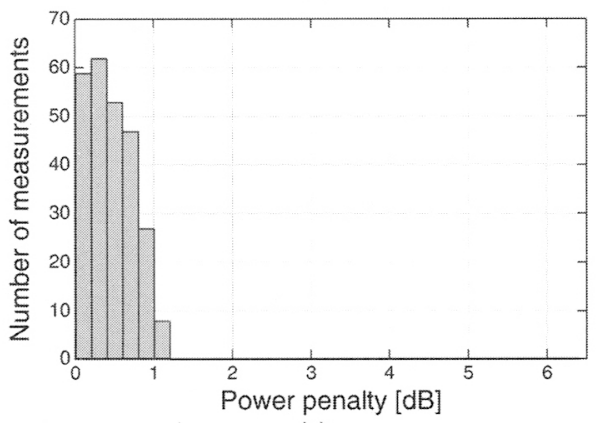

(c)

Fig. 6 Obtained histograms of power penalty when (a) $N=$ 1, (b) $N=2$, and (c) $N=4$, respectively.

Table 1 Measured results.

\begin{tabular}{ccccc}
\hline & & $\begin{array}{c}\text { Average } \\
\text { power penal ty }\end{array}$ & \multicolumn{2}{c}{ Outage probability } \\
& & $1 \mathrm{~dB}$ & $>2 \mathrm{~dB}$ \\
\hline \multirow{2}{*}{$\begin{array}{c}\text { Distributed } \\
\text { FMDC }\end{array}$} & $\mathrm{N}=1$ & $1.0 \mathrm{~dB}$ & 0.36 & 0.08 \\
& $\mathrm{~N}=2$ & $0.9 \mathrm{~dB}$ & 0.29 & 0.04 \\
& $\mathrm{~N}=4$ & $0.4 \mathrm{~dB}$ & 0.03 & 0.00 \\
\hline Fost-PMDC & $0.5 \mathrm{~dB}$ & 0.06 & 0.00 \\
\hline
\end{tabular}

ために行った，偏光制御素子と偏光子で構成した自由度2 の1次PMD補償器 (Fig. 3(e))による結果も示している。分 布型補償での各補償器は1次PMDを部分的にしか補償しな いが，配置数を4とすることで，受信端に配置した1次 PMD補償器よりも小さな平均パワーペナルティと不稼働 率が得られた。この結果は, 従来の受信端に配置された1 次PMD補償器では対応できない, より広帯域のWDM伝送 システムへの適用可能性を示唆するものである。

\section{5. むすび}

本稿では, PMDについて概略を説明し, その光領域で の各種補償方法を説明した。さらに，筆者らが行った， 偏光子を用いた分布型PMD補償実験について述べた。10 
Gbit/sのRZ光送受信機と平均DGDが47 psのPMDエミュ レータを用いて補償実験を行った結果, 自由度1の簡易型 補償器を4段分布的に配置することで, 受信器に配置した 自由度 2 の1次PMD補償器よりも小さな平均パワーペナル ティおよび不稼働率が得られた。

\section{謝 辞}

実験を行うにあたり協力頂いた奈良成記君 (現(株) NTT データ)に謝意を表します。また，偏光子による分布型 PMD補償に関する研究は, 通信・放送機構「トータル光通 信技術の研究開発」および「文部科学省科研費基盤研究 $(\mathrm{S})$ 13852010」の援助を受けた。記して謝意を表します。

\section{参考文献}

1) N. Gisin, J. P. Vonderweid, and J. P. Pellaux: IEEE/OSA J. Lightwave Technol. 9 (1991) 821.

2) H. Kogelnik, R. M. Jposon, and L. E. Nelson: Polarization-mode Dispersion, Optical Fiber Telecommunications IVB, I. Kaminow and T. Li Ed: Academic Express (1990) Chap. 15, pp. 725-861.

3) D. Derickson Ed: Fiber optic test and measurement, Prentice Hall (1998) Chap. 12, pp. 487-495.

4) L. E. Nelson, R. M. Jposon, H. Kogelnik, and G. J. Foschini: IEEE Photon. Tech. Lett. 11 (1999) 1614.

5) S. Betti, F. Curti, B. Daino, G. De Marchis, E. Iannone, and F. Matera: Opt. Lett. 16 (1991) 467.

6) M. Karlsson, J. Brentel, and P. A. Andrekson: IEEE/OSA J.
Lightwave Technol. 18 (2000) 941.

7) M. Brodsky, P. Magill, and N. J. Frigo: IEEE Photon. Tech. Lett. 16 (2004) 209.

8) F. Curti, B. Daino, G. de Marchis, and F. Matera: J. Lightwave Technol. 8 (1990) 1162.

9) P. Noutsios and S. Poirier: Tech. Digest of NFOEC 2001, 1342.

10) H. Sunnerud, C. Xie, M. Karlsson, R. Samuelsson, and P. A. Andrekson: IEEE/OSA J. Lightwave Technol. 20 (2002) 368.

11）瀧口 浩一：偏波モード分散(PMD) 補償デバイス，オプトロニ クス, $21(2002) 66$.

12) T. Ono, S. Yamazaki, H. Shimizu, and H. Emura: IEEE/OSA J. Lightwave Technol. 12 (1994) 891.

13) F. Heismann, D. A. Fishman, and D. L. Wilson: Tech. Digest of ECOC' $98,1,529$.

14) T. Takahashi, T. Imai, and M. Aiki: Electron. Lett. 30 (1994) 348.

15) T.Ozeki and T.Kudou: Tech. Digest of OFC/IOOC'93, WI-9.

16) W. Shieh, H. Haunstein, B. Mckay, D. Fishman, A. Golubchik, J. Diubaldi, C. Martell, V. Arya, R. Lee, and H. Choudhury: Tech. Digest of ECOC2000, 2, 41.

17) Q. Yu, L. Yan, S. Lee, Y. Xie, M. Hauer, Z. Pan, and A. E. Willner: Tech. Digest of ECOC2000, 2, 47.

18) M. Karlsson, H. Sunnerud, and P. A. Andrekson: Tech. Digest of ECOC2000, 2, 33.

19) M. Hayashi, H. Tanaka, and M. Suzuki: Tech. Digest of OECC/ IOOC2001, 48.

20) J. M. Fini and H. A. Haus: IEEE Photon. Tech. Lett. 13 (2001) 124.

21) C. Xie: Tech. Digest of ECOC2002, 7.1.1.

22) D. Alzetta and M. Matsumoto: IEEE Photon. Tech. Lett. 15 (2003) 822.

23）戸田裕之，奈良成記，松本 正行，ダニエレアルゼッタ：信 学技報 (2004) NS2003-247.

24) C. D. Poole and D. L. Favin: IEEE/OSA J. Lightwave Technol. 12 (1994) 917.

25）高橋 哲夫, 中島 和秀, 大橋 正治：O puls E 24 (2002) 999.
偏波モード分散 (polarization mode dispersion; PMD)

通常の単一モードファイバでは, 横方向からの応力ゃ ねじれが加わったり，横断面構造が真円からずれている と複屈折が生じる.ファイバ伝送後の光信号を時間領域 でみると, 発生した複屈折によって二つの直交固有偏光 状態の間に群遅延時間差が生じ, 光信号波形の歪みの原 因となる。この現象を偏波モード分散(PMD) という。単 一モードファイバの複屈折は, 周囲温度や振動などまわ りの環境によっても変化するから, PMDは時間的に変動 する。したがって, PMDの補償には多くの場合, フィー
ドバック制御が用いられる。また，ファイバ長手方向に も複屈折はランダムに変化するから, ファイバ伝送路全 体のPMDの大きさは，ファイバ長の平方根に比例する. そのため, 単一モードファイバのPMDの大きさの評価に はPMD係数Dp[ps/ $\sqrt{\mathrm{km}}]$ が用いられる。PMDは，40 Gbit/ $\mathrm{s}$ ベースの長距離基幹系伝送路を構築する場合や, 既設 ファイバを利用して伝送速度をアップデートする場合 に，留意すべき問題となる。

(戸田裕之) 